\title{
Relationship between Satisfaction with Service Recovery and its Drivers
}

\author{
Aygul Isayeva \\ Guest Lecturer, \\ International Black Sea University, Tbilisi, Georgia
}

\section{Introduction}

Very few customers complain despite having experienced service failure (Stephens and Gwinner, 1998). The reasons for not complaining are plentiful (Vorhees, Brady and Horowitz, 2006) and the consequences are potentially devastating to a company, resulting in increased "opportunity cost" (Fornell and Wernfelt, 1987 and Vorhees et. al., 2006), lost market share and declining profitability (e.g. Estelami, 2000). On the other hand, if the customer complains, it should be considered as a gift (Barlow and Moeller, 1996) and listened to carefully in order to take the right corrective actions, turning the unhappy customers into delighted apostles singing our gospel. Based on the logic of the service recovery paradox, this should be a possibility, at least theoretically. Still, the support for such effects is mixed and seems to depend on situational factors such as the cause and severity of the failure and whether the company had control over the failure (Magnini, Ford, Markowski and Honeycutt, 2007). To mention but a few, complaint handling provides information to improve products/services, positive customer attitudes, increased repurchase intentions, positive word-of-mouth and communication about the provider (Stauss and Seidel, 2004, Stauss and Schoeler, 2004). Lately, Luo and Homburg (2008) have even found that complaint handling has a stronger effect on stock value gap than customer satisfaction. Also, an efficient service recovery should prevent double deviation situations, i.e. inappropriate or inadequate response to a failure (Johnston and Fern, 1999) turning a bad situation into an even worse one. In order to develop efficient service recovery systems, collect the benefits and avoid double deviation situations, there is a need to understand the customer's situation. From earlier work it is known that personal and situational factors have an impact on customers' assessments of service delivery and their level of satisfaction (e.g. Wilson, Zeithaml, Bitner and Gremler, 2008). Also, customers engage in different types of relationships with service providers (Gutek, Cherry, Bhappu, Schneider and Woolf, 2000), for instance service encounters, pseudo relationships or true relationships (Gutek et. al., 2000) or they may be 
acquaintances, friends or partners with the service provider (Johnson and Selnes, 2004). One of the first studies to investigate the effects of complaint handling on customer relationships was conducted by Tax, Brown and Chandrashekaran (1998). They looked at how the interplay between satisfaction with complaint handling and previous experience affect trust and commitment.

Current research on the antecedents of customer satisfaction and customer satisfaction with service recovery (Szymanski and Henard, 2001; Tor Andreassen, 2000) has mainly focused on five antecedents; equity, initial negative affect, expectations, performance and disconfirmation. The correlations between these and customer satisfaction, however, vary from study to study and are not constantly high. As an example, Andreassen (2000) found a correlation between equity and satisfaction of 0.34 and a correlation between disconfirmation and satisfaction of 0.29. In their meta-analysis Szymanski and Henard (2001) show that the correlations for disconfirmation with satisfaction range from -0.24 to 0.87 and the values of the correlations for equity with satisfaction range from -0.14 to 0.87 . According to my opinion, these studies do not take into account differences in the relationship between customer and firm, and that this research may provide clearer results. In the proposed model of antecedents to customer satisfaction with service recovery, I look only at the three dimensions of perceived justice and disconfirmation, as opposed to all five dimensions stated above. Disconfirmation is a variable that encompasses the variables of performance and expectation, making the latter two redundant.

I am making some assumptions in order to limit the dimensions of the problem statement. Firstly, I assume the service failure is recognized as being of high severity to the customer, which is to say, is a relatively great matter to the dissatisfied customer. As I discuss service recovery, this naturally means that the customer has been given dissatisfaction. Secondly, it is necessary to note that I define all recoveries to be service recovery, no matter whether the failure itself is on a product or service, tangible or intangible, durable or non durable. I do not differentiate services from goods, by taking into account the suggestion of Vargo and Lusch (2004) that all economic exchange is a service.

\section{Literature Review and Hypotheses}

In the following I will review research done on each variable, point to limitations in prior research and introduce my contribution. I will review the research of service recovery and satisfaction before I go through the proposed antecedents of 
customer satisfaction with service recovery, linking them to customer satisfaction and thereby stating my hypotheses.

\section{Customer Satisfaction with Service Recovery}

The service recovery paradox suggests that customers might end up more satisfied after experiencing an excellent recovery than what they were from the start having no service failure. According to McCollough and Bharadwaj (1992), Service Recovery Paradox refers to a situation in which a customer's post-failure satisfaction exceeds pre-failure satisfaction. Hart, Heskett and Sasser's (1990: 148) academic paper is the most cited about service recovery paradox, stating: "a good recovery can turn angry, frustrated customers into loyal ones. It can in fact create more goodwill than if things had gone smoothly in the first place." Moreover, Hart et al. (1990) show that "doing things right the second time" can turn complaining customers into very satisfied ones. However, there is no guarantee of making a customer satisfied, and how satisfied a customer might become or not become depends on many factors.

\section{Drivers to Satisfaction with Service Recovery}

Oliver (1997:194) defines equity as "a fairness, rightness, or deservingness in comparison to other entities, whether real or imaginary, individual or collective, person or non-person." The perceived justice as a component of equity theory consists of three dimensions: distributive justice, procedural justice and interactional justice (Tax et. al., 1998).

Based on social exchange theory Adams (1963) argues that distributive justice refers to the role of "equity," where individuals assess fairness of an exchange by comparing their inputs to outcomes. Ruyter and Wetzels (2000) define distributional fairness as the manner in which inputs and outputs are divided between the parties: in other words, what specific outcome (output) has been offered to the customer to recover from the service failure and whether this outcome offsets the costs (input) of the service failure (Greenberg, 1990; Gilliland, 1993). To mend or totally replace the product or re-perform the service, apologies, and compensation (e.g. gratis, discounts, coupons, free upgrades, and free ancillary) are considered typical distributive outcomes (Goodwin and Ross, 1992; Hoffman and Kelly, 2000; Tax et al.1998). 
The second component of perceived justice, procedural fairness, represents the fairness of the process that leads to a certain outcome and aims to resolve conflicts (Tax et al 1998). According to Greenberg (1990) it examines the process that is undertaken to arrive at the final outcome. Customers want to have a "voice," in other words, they want to be active (Goodwin and Ross, 1992).

Tax et al. (1998) define interactional justice, the third component of perceived justice, as "dealing with interpersonal behavior in the enactment of procedures and the delivery of outcomes." Wirtz and Mattila (2004) demonstrate an apology, perceived helpfulness, courtesy, and empathy as an example of interactional treatment during the service recovery process. According to Maxham and Netemeyer (2002) interactional justice is the extent to which customers feel that they have been treated fairly regarding their personal interaction with service agents throughout the recovery process.

Some research has examined the effects of perceived justice on service recovery (Blodgett, Granbois and Walters. 1993; McCollough, Berry and Yadav, 2000; Smith, Bolton and Wagner, 1999; Tax et al., 1998); however, these studies do not take into account the effects of perceived justice dimensions on satisfaction with service recovery. Thus, it would be interesting to analyze how offering justice in service recovery will affect gaining customer satisfaction.

As mentioned in the introduction, disconfirmation is affected by the consumer expectation of performance and the service provider's performance, in other words "a function of recovery expectations and recovery performance" (Magnini et al., 2007: 214). Oliver (1997) says that disconfirmation refers to the psychological interpretation of an expectation. In other words, this can be expressed as the performance being better or worse than what the customers expected.

The objective of this research is to test a perceived justice, disconfirmation and satisfaction-based model of the service recovery process as it takes place over time. Before a customer comes to evaluate satisfaction with a service recovery, he or she will have gone through a failure-to-recovery process. Firstly, a service or product failure occurs, which will lead to initial negative affect, which creates dissatisfaction. This will be answered by the firm performing a service recovery. It is then the customers' perception of this service recovery that will determine the degree of satisfaction.

The preceding discussion and arguments result in the following hypothesis:

\section{$H_{1}$ : Distributive justice has a positive impact on satisfaction with service recovery.}


$\mathrm{H}_{2}:$ Procedural justice has a positive impact on satisfaction with service recovery.

$H_{3}:$ Interactional justice has a positive impact on satisfaction with service recovery.

$\mathrm{H}_{4}$ : Disconfirmation has a positive impact on satisfaction with service recovery.

The conceptual model summarizes the hypotheses in Figure 1:

Figure 1: The conceptual model

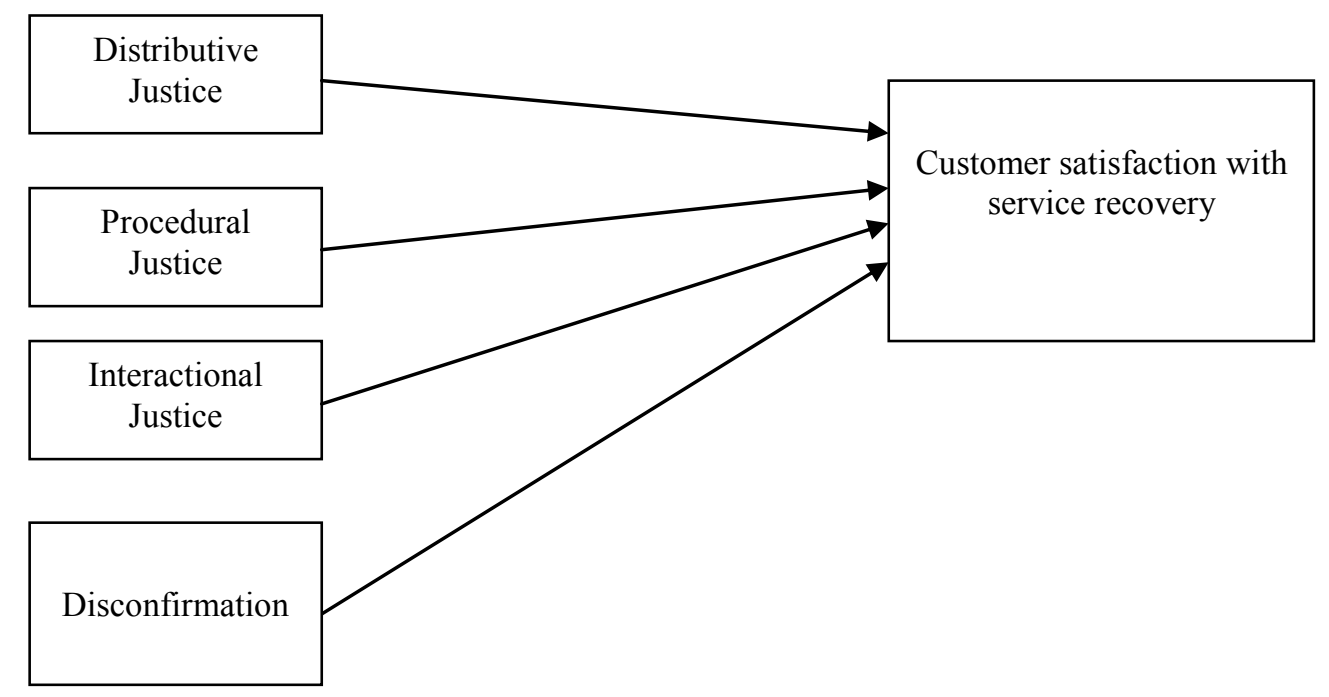

In the conceptual model I demonstrate the relationship between these antecedents and customer satisfaction with service recovery.

\section{Methodology}

A quantitative design was chosen for the purpose of this study. A questionnaire was developed and data collected through a survey. The sample consisted of customers from an international hotel chain. Following pre-testing, the study investigated customers who faced service recovery after service failure and was conducted on a convenience sample of respondents of 300 customers. Because of missing values, 284 from the total 300 surveys were retrieved and used for further analysis. The research result shows that $37.7 \%$ of the customers experienced a situation that produced dissatisfaction more than 8 months ago and $29.2 \%$ of the respondents expressed their dissatisfaction half a year ago. 52.1\% of the customers 
Aygul Isayeva

did verbally complaint to the hotel, where the main preferred approach was face-toface (53.2\%). In general, $41.5 \%$ of the customers expressed dissatisfaction about a product and service 3-4 times in the course of the past year (see Appendix).

The sample exhibited the following demographic characteristics: the final sample contained $60.6 \%$ males and $39.4 \%$ females. Most of the respondents were business customers $(86.6 \%)$. Descriptive statistics indicates that $83.8 \%$ of the customers stayed more than 6 nights per year. Most respondents were in the age group of 3645 (59.9\%). The educational background of the sample varied, with $10.6 \%$ having some high school, $19.7 \%$ college/university undergraduates, $56.3 \%$ college/university graduates and $8.8 \%$ having further education after college/university. According to households' yearly gross income, most of the respondents were in the groups of 500,000-749,999 (25.4\%) and 749,999-999,999 (25.4\%) (see Appendix).

\section{Measures}

All the variables considered were measured on a 7-point Likert scale. The questions used to measure the variables in the conceptual model are all based on well-established scales from previous research, i.e. the measure of satisfaction with service recovery is based on Andreassen $(1997,2000)$. The scales for distributive, procedural and interactional justice were taken from Voorhees and Brady (2005), while the disconfirmation scale was based on Oliver's (1980) work. The operationalization of Oliver's $(1997,1999)$ loyalty phases was based on the modified scales by Harris and Goode (2004).

\section{Analysis of data}

Reliability was examined via the Cronbach alpha coefficient. Nunnally (1967) argues that a score above 0.5 is reliable for basic research, however the score over 0.70 is proposed in the literature (Nunnally, 1978). Reliability constructs were high for satisfaction with service recovery (0.841), distributive justice (0.968), procedural justice (0.927), and interactional justice (0.958). However, no reliability information was reported for disconfirmation by Oliver (1980). At the same time, the scale does not have a high level of reliability in this study either (0.131).

Taking these into account I believe that the scales are reliable and meet the proposed thresholds (see table 1). 
Table 1: Cronbach's alpha for the measures employed in this study

\begin{tabular}{|l|l|l|}
\hline Measures & Chronbach's alpha & Number of items \\
\hline SSR & 0.841 & 3 \\
\hline Distributive Justice & 0.968 & 5 \\
\hline Procedural Justice & 0.927 & 5 \\
\hline Interactional Justice & 0.958 & 5 \\
\hline Disconfirmation & 0.131 & 2 \\
\hline
\end{tabular}

\section{Results and Tests of Hypotheses}

With a sample consisting of 284 customers I decided to run multiple regression analyses in order to test the conceptual model and the hypotheses. In regression analysis, distributive, procedural and interactional justice and disconfirmation were entered as the independent variables and satisfaction with service recovery as the dependent variable. Based on the results from these analyses, I identified certain patterns and effects that need further research. First, at this point in time, I see that the conceptual model replicates well. I find support for the model in the data set and the model provides a relatively high $\mathrm{R}^{2}$ of .645 or $64.5 \%$ in the first step, where only the drivers' effect on satisfaction with service recovery are measured. All the drivers, i.e. justice dimensions and disconfirmation, have significant effects on satisfaction with service recovery. Of the variables, distributive justice seems more important, followed by procedural justice, interactional justice and disconfirmation respectively. The two latter variables have negative effects on the dependent variable. When I analyze the pattern and strength of the relationship between satisfaction with service recovery and its drivers, I find indications of that these relationships are high (see table 2).

Table 2. Model Summary

\begin{tabular}{|l|l|l|l|l|l|}
\hline \multirow{2}{*}{ Model } & \multirow{2}{*}{ R Square } & \multirow{2}{*}{$\begin{array}{c}\text { Adjusted R } \\
\text { Square }\end{array}$} & $\begin{array}{c}\text { R Square } \\
\text { Change }\end{array}$ & F Change & Sig. F Change \\
\hline 1 & .645 & .640 & .645 & 121.458 & .000 \\
\hline
\end{tabular}

The ANOVA table indicates that the model as a whole is significant $(F=122.823, p<0.005)$. 
ANOVA $^{1}$

\begin{tabular}{|l|l|l|l|l|l|}
\hline \multicolumn{1}{|c|}{ Model } & $\begin{array}{c}\text { Sum of } \\
\text { Squares }\end{array}$ & \multicolumn{1}{c|}{ df } & $\begin{array}{c}\text { Mean } \\
\text { Square }\end{array}$ & \multicolumn{1}{|c|}{ F } & Sig. \\
\hline Regression & 252,919 & 4 & 63,230 & 122,823 &, $000^{2}$ \\
Residual & 138,998 & 270 &, 515 & & \\
Total & 391,917 & 274 & & & \\
\hline
\end{tabular}

The findings in this study confirm that distributive justice is most significantly and positively related to SSR. Distributive justice has a beta value of 0.619 at $\mathrm{p}<0.05$, thus supporting $\boldsymbol{H}_{\boldsymbol{I}}$ (see table 3). Moreover, the Pearson Correlation presented in Table 4 shows that there is a positive relationship between distributive justice and SSR $(r=0.688)$. The relationship between these two variables was significant $(0.000)$.

$\boldsymbol{H}_{2}$ argues that procedural justice has a positive impact on satisfaction with service recovery. Beta values indicate strong support for this claim. Procedural justice has a beta coefficient of 0.563 at $\mathrm{p}<0.05$ (see table 3). Moreover, the results of the Pearson Correlation presented in Table 4 indicate that a strong correlation between procedural justice and SSR $(\mathrm{r}=0.727)$ was significant $(\mathrm{p}=0.000)$.

$\boldsymbol{H}_{3}$ contends that interactional justice has a positive impact on satisfaction with service recovery. Interactional justice has a beta value of $(-0.353)$ in at $\mathrm{p}<0.05$ (see table 3). Moreover the correlation matrix, displayed in Table 4, generates support for this view with a positive $(\mathrm{r}=0.525)$ and significant $(\mathrm{p}=0.000)$ bivariate association.

$\boldsymbol{H}_{4}$ reasons that disconfirmation has a positive impact on satisfaction with service recovery. The multiple regression analysis shows the effect of disconfirmation on SSR with an absolute beta value of $(-0.117)$ at $\mathrm{p}<0.05$ (see table 3 ). Moreover, the correlation matrix indicates that a positive correlation between disconfirmation and $\operatorname{SSR}(\mathrm{r}=0.034)$ was significant $(\mathrm{p}<0.05)$ (see table 4$)$.

\footnotetext{
${ }^{1}$ Dependent Variable: SSR

${ }^{2}$ Predictors: (Constant), Disconfirmation, Procedural_Justice, Distributive_Justice, Interactional_Justice
} 
Table 3: Coefficients

\begin{tabular}{|ll|l|l|l|}
\hline \multicolumn{2}{|l|}{ Model } & Beta Coefficients & $\mathrm{t}$ & Sig. \\
\hline $1 \quad$ (Constant) & & 4.925 & .000 \\
& Distributive_Justice & .619 & 9.285 & .000 \\
& Procedural_Justice & .563 & 11.018 & .000 \\
& Interactional_Justice & -.353 & -5.232 & .000 \\
& Disconfirmation & -.117 & -2.979 & .003 \\
\hline
\end{tabular}

Table 4: Correlations

\begin{tabular}{|l|l|l|}
\hline Pearson Correlation & SSR & 1.000 \\
& Distributive_Justice & .688 \\
& Procedural_Justice & .727 \\
& Interactional_Justice & .525 \\
& Disconfirmation & .034 \\
\hline
\end{tabular}

Based on these early results I can draw conclusions that $\boldsymbol{H}_{1}, \boldsymbol{H}_{2}, \boldsymbol{H}_{3}$, and $\boldsymbol{H}_{4}$ are supported.

\section{Conclusion}

This study aimed to explore the impact of the dimensions of perceived justice and disconfirmation on SSR. Four different hypotheses were developed and tested. In my preliminary findings, support was found for all of the hypotheses. As the regression analysis revealed, the three justice dimensions and disconfirmation were significantly positively related to SSR.

The results of this research have important implications for managers and firms as they could gain a greater understanding of their customers, which can make companies become more profitable in the long run. To be able to attract and retain loyal and profitable customers, it is an advantage to increase understanding of customer attitudes and involvement with a product or service category.

The results indicate that the perception of fairness in the outcome of the dissatisfaction is more important than the disconfirmation of expectations of service recovery. This study suggests that offering distributive, procedural and 
interactional justice following failures may increase customers' satisfaction. Thus, the research result suggests that managers should strive to offer customers fair outcomes, procedures, and personal interactions.

According to Hart et al. (1990) there is a gap between service companies that manage complaints well and those that do not. It is in companies' best interest to encourage dissatisfied customers to complain; however, little guidance is available to managers on how to encourage complaints. Treating customers fairly during dissatisfying service encounters can increase complaint intentions and reap future benefits for managers. It is also important to note that future research should consider the effects of prominent service variables that may be worthy of investigation in the context of complaining.

\section{References and Notes:}

Adams, J.S. 1963, 'Toward an understanding of inequity.' Journal of Abnormal and Social Psychology, vol. 67, 5, pp. 422-436.

Andreassen, Tor Wallin. 1997, 'Dissatisfaction with services: The impact of satisfaction with service recovery on corporate image and future repurchase intension.' School of Business Research Report no. 5. Stockholm: Stockholm University.

Andreassen, Tor Wallin. 2000, 'Antecedents to satisfaction with service recovery,' European Journal of Marketing, vol. 34, no 1/2, pp. 156- 175.

Barlow, J. and C. Moeller 1996, 'A complaint is a gift,' San Francisco: Berrett-Koehler Publishers.

Blodgett J. G, Granbois D. H. and Walters R.G. 1993, 'The effects of perceived justice on complainants' negative word-of-mouth behaviour and repatronage intentions,' Journal of Retailing, vol. 69, pp. 399-427.

Estelami Hooman 2000, 'Competitive and Procedural Determinants of Delight and Disappointment in Consumer Complaint Outcomes', Journal of Service Research, vol. 2, no.3, pp. 16-285.

Fornell, C. \& Wernfelt, B. 1987, 'Defensive Marketing Strategy by Customer Complaint Management: A Theoretical Analysis,' Journal of Marketing Research, vol. 24, pp. 337-346.

Gilliland, S.W. 1993, 'The perceived fairness of selection systems: an organizational justice perspective,' Academy of Management Review, vol. 18, no. 4, pp. 697-734.

Goodwin, C. and Ross, I. 1992, 'Consumer response to service failures: influence of procedural and interactional fairness perceptions,' Journal of Business Research, vol. 25, pp. 149-163.

Greenberg, J. 1990, 'Organizational justice: yesterday, today and tomorrow,' Journal of Management, vol. 16, no. 2, pp. 399-432.

Gutek Barbara A., Cherry Bennett, Bhappu Anita D., Schneider Sherry, Woolf Loren 2000,'Features of Service Relationships and Encounters.' Work and Occupations, vol. 27 , no. 3, pp. 319-352. 
Hart, C., Heskett, J. and Sasser, E. 1990, 'The profitable art of service recovery,' Harvard Business Review, vol. 68, no. 4, pp. 148-156.

Harris, Lloyd C. and Goode Mark. M. H. 2004, 'The four levels of loyalty and the pivotal role of trust: a study of online service dynamics,' Journal of Retailing, vol. 80, pp. 139-158.

Hoffman K.D. and Kelly S.W 2000, 'Perceived justice and recovery evaluation: a contingency approach,' European Journal of Marketing, vol. 34, no. 3/4, pp. 418-432.

Johnston, Robert; Fern, Adrian 1999, 'Service Recovery Strategies for Single and Double Deviation Scenarios,' Service Industries Journal, vol. 19, no. 2, pp. 69-82.

Johnson Michael D. and Selnes Fred 2004, 'Customer Portfolio Management: Toward a Dynamic Theory of Exchange Relationships,' Journal of Marketing, vol. 68, no. 2, pp. $1-17$.

Luo, Xueming; Homburg, Christian 2008, 'Satisfaction, Complaint, and the Stock Value Gap,' Journal of Marketing, vol. 72, no. 4, pp. 29-43.

Magnini, Vincent P., John B. Ford, Edward P. Markowski and Earl D. Honeycutt Jr. 2007, 'The service recovery paradox: justifiable theory or smoldering myth?' Journal of Service Marketing, vol. 21, no. 3, pp. 213-225.

Maxham James G. and Richard G. Netemeyer 2002, 'Modeling customer perceptions of complaint handling over time: the effects of perceived justice on satisfaction and intent,' Journal of Retailing, vol. 78, pp. 239-252.

McCollough M. A, Berry L. L and Yadav M. S. 2000, 'An empirical investigation of customer satisfaction after service failure and recovery,' Journal of Service Research, vol. 3, pp. 626-637.

McCollough, M. and Bharadwaj, S. 1992, 'The recovery paradox: an examination of consumer satisfaction in relation to disconfirmation, service quality, and attribution based theories.' in Allen, C. and Madden, T. (Eds), Marketing theory and Applications, American Marketing Association, Chicago, IL.

Nunnally J.C. 1967, 'Psychometric Theory,' 1st edition, McGraw-Hill, New York, NY.

Nunnally J.C. 1978, 'Psychometric Theory,' 2nd edition, McGraw-Hill, New York, NY.

Oliver, Richard L. 1997, 'Satisfaction: A Behavioral Perspective on the Consumer,' New York: McGraw-Hill.

Oliver, Richard L. 1980, 'A Cognitive Model of the Antecedents and Consequences of satisfaction Decisions,' Journal of Marketing research, vol. 17, November, pp. 460-69.

Oliver, Richard L. 1999, 'Whence Consumer Loyalty,' Journal of Marketing, vol. 63, Special issue, pp. 33-44.

Ruyter K. and Wetzels M. 2000, 'Customer equity considerations in service recovery: a cross-industry perspective,' International Journal of Service Industry Management, vol. 11, no. 1, pp. 91-108.

Smith A. K., Bolton R. N and Wagner J. 1999, 'A model of customer satisfaction with service encounters involving failure and recovery,' Journal of Service Research, vol. 36, pp. 356-373.

Stephens Nancy and Gwinner Kevin P. 1998, 'Why Don't Some People Complain? A Cognitive-Emotive Process Model of Consumer Complaint Behavior,' Journal of the Academy of Marketing Science, vol. 26, no. 3, pp. 172-189. 
Stauss, B., Seidel, W. 2004, 'Complaint Management - The Heart of CRM,' Mason, Ohio, USA.

Stauss Bernd and Andreas Schoeler, 2004, 'Complaint management profitability: what do complaint managers know?' Managing Service Quality, vol. 14, no. 2/3, pp. 147 156.

Szymanski, David M. and David H. Henard, 2001, 'Customer Satisfaction: A MetaAnalysis of the Empirical Evidence,' Journal of Academy of Marketing Science, vol. 29, no. 1, pp. 16-35.

Tax, S.S, Brown, S.W. and Chandrashekaran, M. 1998, 'Customer evaluations of service complaint experiences: implications for relationship marketing.' Journal of Marketing, vol. 62, April, pp. 60-76.

Vargo L. Stephen and Robert F. Lusch, 2004, 'The four service marketing myths: remnants of a goods-based, manufacturing model,' Journal of Service Research, vol. 6, May, pp. 324-335.

Voorhees M. Clay and Michael K. Brady, 2005, 'A Service Perspective on the Drivers of Complaint Intentions.' Journal of Service Research, vol. 8, November, pp. 192- 204.

Voorhees M. Clay, Michael K. Brady, and David M. Horowitz, 2006, 'A Voice From the Silent Masses: An Exploratory and Comparative Analysis of Noncomplainers,' Journal of the Academy of Marketing Science, vol. 34, no. 4, pp. 514-527.

Wilson Alan, Zeithaml Valerie A., Mary Jo Bitner, Dwayne D. Gremler, 2008, 'Services marketing: integrating customer focus across the firm,' European ed. McGraw-Hill. 576

Wirtz, J. and Mattila A.S. 2004, 'Consumer responses to compensation, speed of recovery and apology after a service failure,' International Journal of Service Industry Management, vol. 15, no. 2, pp. 150-166. 


\section{Appendix - Descriptive Statistics}

\section{Experienced_dissatisfaction}

\begin{tabular}{|ll|r|r|r|r|}
\hline & Frequency & Percent & Valid Percent & $\begin{array}{c}\text { Cumulative } \\
\text { Percent }\end{array}$ \\
\hline Valid & Less than one month ago & 34 & 12,0 & 12,0 & 12,0 \\
& $1-2$ months ago & 20 & 7,0 & 7,1 & 19,1 \\
& $3-4$ months ago & 31 & 10,9 & 11,0 & 30,0 \\
& $5-6$ months ago & 61 & 21,5 & 21,6 & 51,6 \\
& $7-8$ months ago & 18 & 6,3 & 6,4 & 58,0 \\
& More than 8 months ago & 107 & 37,7 & 37,8 & 95,8 \\
& Not sure & 12 & 4,2 & 4,2 & 100,0 \\
& Total & 283 & 99,6 & 100,0 & \\
Missing & Does not want to say & 1 &, 4 & & \\
Total & 284 & 100,0 & & \\
\hline
\end{tabular}

Last_express_dissatisfaction

\begin{tabular}{|ll|r|r|r|r|}
\hline & & & & \multicolumn{1}{c|}{$\begin{array}{c}\text { Cumulative } \\
\text { Percent }\end{array}$} \\
\hline Valid & A couple of days ago & 13 & 4,6 & 4,8 & 4,8 \\
& A couple weeks ago & 28 & 9,9 & 10,4 & 15,2 \\
& Last month & 52 & 18,3 & 19,3 & 34,4 \\
& Half a y ear ago & 83 & 29,2 & 30,7 & 65,2 \\
& A year ago & 30 & 10,6 & 11,1 & 76,3 \\
& More than two years ago & 64 & 22,5 & 23,7 & 100,0 \\
& Total & 270 & 95,1 & 100,0 & \\
Missing & Don't remember & 14 & 4,9 & & \\
Total & & 284 & 100,0 & & \\
\hline
\end{tabular}


Dissatisfied_action

\begin{tabular}{|c|c|c|c|c|c|}
\hline & & Frequency & Percent & Valid Percent & $\begin{array}{l}\text { Cumulative } \\
\text { Percent }\end{array}$ \\
\hline \multirow[t]{6}{*}{ Valid } & $\begin{array}{l}\text { Expressed } \\
\text { dissatisfaction, but } \\
\text { did not complain }\end{array}$ & 67 & 23,6 & 25,2 & 25,2 \\
\hline & $\begin{array}{l}\text { Verbal complaint to } \\
\text { the hotel }\end{array}$ & 148 & 52,1 & 55,6 & 80,8 \\
\hline & $\begin{array}{l}\text { Written complaint to } \\
\text { the hotel }\end{array}$ & 44 & 15,5 & 16,5 & 97,4 \\
\hline & Hired a lawyer & 6 & 2,1 & 2,3 & 99,6 \\
\hline & $\begin{array}{l}\text { To the consumeræs } \\
\text { council }\end{array}$ & 1 & ,4 & ,4 & 100,0 \\
\hline & Total & 266 & 93,7 & 100,0 & \\
\hline Missing & Did not do any thing & 18 & 6,3 & & \\
\hline Total & & 284 & 100,0 & & \\
\hline
\end{tabular}

Preferred_communication

\begin{tabular}{|ll|r|r|r|r|}
\hline & & & & \multicolumn{2}{c|}{ Cumulative } \\
& & Frequency & Percent & Valid Percent \\
\hline Valid & Letter & 9 & 3,2 & 3,2 & 3,2 \\
& E-mail & 107 & 37,7 & 37,7 & 40,8 \\
& Telephone & 17 & 6,0 & 6,0 & 46,8 \\
Face-to-face & 151 & 53,2 & 53,2 & 100,0 \\
Total & 284 & 100,0 & 100,0 & \\
\hline
\end{tabular}

Times_expressed_dissatisfaction

\begin{tabular}{|ll|r|r|r|r|}
\hline & & & & \multicolumn{1}{c|}{$\begin{array}{c}\text { Cumulative } \\
\text { Percent }\end{array}$} \\
\hline Valid & Zero & 12 & 4,2 & 4,2 & 4,2 \\
& $1-2$ times & 98 & 34,5 & 34,5 & 38,7 \\
& $3-4$ times & 118 & 41,5 & 41,5 & 80,3 \\
& $5-6$ times & 50 & 17,6 & 17,6 & 97,9 \\
& More than 7 times & 6 & 2,1 & 2,1 & 100,0 \\
Total & 284 & 100,0 & 100,0 & \\
\hline
\end{tabular}




\section{Gender}

\begin{tabular}{|ll|r|r|r|r|}
\hline & & & & \multicolumn{1}{c|}{$\begin{array}{c}\text { Cumulative } \\
\text { Percent }\end{array}$} \\
\hline Valid & Male & 172 & 60,6 & 60,6 & 60,6 \\
& Female & 112 & 39,4 & 39,4 & 100,0 \\
& Total & 284 & 100,0 & 100,0 & \\
\hline
\end{tabular}

Visit_purpose

\begin{tabular}{|c|c|c|c|c|c|}
\hline & & Frequency & Percent & Valid Percent & $\begin{array}{c}\text { Cumulative } \\
\text { Percent }\end{array}$ \\
\hline \multirow[t]{6}{*}{ Valid } & Business & 246 & 86,6 & 86,6 & 86,6 \\
\hline & Leisure & 25 & 8,8 & 8,8 & 95,4 \\
\hline & Meeting/Conf erence & 11 & 3,9 & 3,9 & 99,3 \\
\hline & Tour & 1 & ,4 & ,4 & 99,6 \\
\hline & Celebration & 1 & , 4 & , 4 & 100,0 \\
\hline & Total & 284 & 100,0 & 100,0 & \\
\hline
\end{tabular}

\section{Stay_nights}

\begin{tabular}{|c|c|c|c|c|c|}
\hline & & Frequency & Percent & Valid Percent & $\begin{array}{c}\text { Cumulativ e } \\
\text { Percent }\end{array}$ \\
\hline \multirow[t]{4}{*}{ Valid } & 1-3 nights & 19 & 6,7 & 6,7 & 6,7 \\
\hline & 4-5 nights & 27 & 9,5 & 9,5 & 16,2 \\
\hline & More than 6 nights & 238 & 83,8 & 83,8 & 100,0 \\
\hline & Total & 284 & 100,0 & 100,0 & \\
\hline
\end{tabular}

Age_group

\begin{tabular}{|lr|r|r|r|r|}
\hline & & & & \multicolumn{2}{c|}{$\begin{array}{c}\text { Cumulative } \\
\text { Percent }\end{array}$} \\
\hline Valid & $18-25$ & 5 & 1,8 & 1,8 & 1,8 \\
& $26-35$ & 72 & 25,4 & 25,4 & 27,1 \\
& $36-45$ & 170 & 59,9 & 59,9 & 87,0 \\
$46-55$ & 33 & 11,6 & 11,6 & 98,6 \\
& $56-65$ & 4 & 1,4 & 1,4 & 100,0 \\
& Total & 284 & 100,0 & 100,0 & \\
\hline
\end{tabular}


Education_level

\begin{tabular}{|ll|r|r|r|r|}
\hline & Frequency & Percent & Valid Percent & \multicolumn{1}{c|}{$\begin{array}{c}\text { Cumulative } \\
\text { Percent }\end{array}$} \\
\hline Valid & 30 & 10,6 & 11,1 & 11,1 \\
& $\begin{array}{l}\text { High school } \\
\text { College/university, } \\
\text { undergraduate }\end{array}$ & 56 & 19,7 & 20,7 & 31,7 \\
& $\begin{array}{l}\text { College/university, } \\
\text { graduate }\end{array}$ & 160 & 56,3 & 59,0 & 90,8 \\
& $\begin{array}{l}\text { Further education after } \\
\text { college/univ ersity (PhD } \\
\text { or equivalent) }\end{array}$ & 25 & 8,8 & 9,2 & 100,0 \\
& $\begin{array}{l}\text { Total } \\
\text { Missing }\end{array}$ & 271 & 95,4 & 100,0 & \\
Total & Does not want to say & 13 & 4,6 & & \\
\hline
\end{tabular}

Household's_yearly_gross_income

\begin{tabular}{|c|c|c|c|c|c|}
\hline & & Frequency & Percent & Valid Percent & $\begin{array}{c}\text { Cumulative } \\
\text { Percent }\end{array}$ \\
\hline \multirow[t]{8}{*}{ Valid } & Under 200000 & 3 & 1,1 & 1,1 & 1,1 \\
\hline & 200000-299999 & 5 & 1,8 & 1,8 & 2,8 \\
\hline & 300000-399999 & 11 & 3,9 & 3,9 & 6,7 \\
\hline & $400000-499999$ & 15 & 5,3 & 5,3 & 12,0 \\
\hline & $500000-749999$ & 72 & 25,4 & 25,4 & 37,3 \\
\hline & 750000-999999 & 72 & 25,4 & 25,4 & 62,7 \\
\hline & Over 1 Million & 106 & 37,3 & 37,3 & 100,0 \\
\hline & Total & 284 & 100,0 & 100,0 & \\
\hline
\end{tabular}




\title{
SUMMARY
}

\section{Relationship between Satisfaction with Service Recovery and its Drivers}

\author{
Aygul Isayeva \\ Guest Lecturer, \\ International Black Sea University, Tbilisi, Georgia
}

Service failures are inevitable. Customers tend to complain when they happen. Given that we are able to make customers complain, what actions should we take? This study is aimed at shedding the light on the relationship between satisfaction with service recovery (SSR) and its antecedents - disconfirmation, encompassing the relationship between expectations and performance, and dimensions of perceived justice. As a result, a literature review was carried out in order to reveal how previous research has treated this topic. Based on existing theory and subjective pre-assumptions, 4 hypotheses were proposed. Preliminary findings support the hypotheses.

Keywords: Customer Satisfaction with Service Recovery, Disconfirmation, Perceived Justice. 